\title{
Genetic diversity of the Neotropical otter (Lontra longicaudis Olfers, 1818) in Southern and Southeastern Brazil
}

\author{
Trinca, CS. ${ }^{\mathrm{a}, \mathrm{c}}$, Waldemarin, $H F^{\mathrm{b}}{ }^{\mathrm{b}}$ and Eizirik, E. ${ }^{\mathrm{c}, \mathrm{d} *}$ \\ aDepartamento de Genética, Universidade Federal do Rio Grande do Sul - UFRGS, \\ CEP 91501-970, Porto Alegre, RS, Brazil

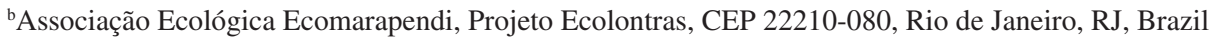 \\ 'Laboratório de Biologia Genômica e Molecular, Faculdade de Biociências, \\ Pontifícia Universidade Católica do Rio Grande do Sul - PUCRS, \\ Av. Ipiranga 6681, prédio 12 C, sala 172, Bairro Partenon, CEP 90619-900, Porto Alegre, RS, Brazil \\ dInstituto Pró-Carnívoros, CEP 12945-010, Atibaia, SP, Brazil \\ Received May 25, 2007 - Accepted August 30, 2007 - Distributed December 1, 2007 \\ *e-mail: eduardo.eizirik@pucrs.br \\ (With 1 figure)
}

\begin{abstract}
The Neotropical otter is one of the least known otter species, and it is considered to be threatened to various degrees throughout its geographic range. Little information exists on the ecological characteristics of this species, and no genetic study has been published about it until now, hampering the design of adequate conservation strategies for its populations. To contribute with genetic information to comprehensive conservation efforts on behalf of L. longicaudis, we characterized the molecular diversity of the 5 ' portion of the mtDNA control region in samples from this species collected in Southern and Southeastern Brazil. The sequence analysis revealed a high level of haplotype diversity $(\mathrm{h}=0.819 ; \mathrm{SE}=0.0052)$ and nucleotide variability ranging from 0.0039 to 0.0067 . One of the sampled haplotypes was the most common in both regions and, from this sequence, several other (locally occurring) haplotypes could be derived by single point mutations. No significant genetic differentiation was observed between the Southern and Southeastern regions.
\end{abstract}

Keywords: Lontra longicaudis, mitochondrial DNA, control region, genetic diversity.

\section{Diversidade genética da lontra Neotropical (Lontra longicaudis Olfers, 1818) no Sul e Sudeste do Brasil}

\begin{abstract}
Resumo
A lontra Neotropical é uma das espécies de lontras menos conhecidas e apresenta diferentes graus de ameaça ao longo de sua distribuição geográfica. Pouca informação existe a respeito de aspectos ecológicos desta espécie e nenhum estudo genético foi publicado até o momento, dificultando a delimitação de estratégias adequadas de conservação para suas populações. Para contribuir com informação genética aos esforços de conservação de L. longicaudis, a diversidade molecular da porção 5' da região controladora do DNA mitocondrial foi caracterizada em amostras desta espécie coletadas nas regiões Sul e Sudeste do Brasil. A análise das seqüências revelou um alto nível de diversidade haplotípica $(\mathrm{h}=0,819 ; \mathrm{SE}=0,0052)$ e variabilidade nucleotídica entre 0,0039 a 0,0067. Um dos haplótipos encontrados foi o mais comum em ambas as regiões e, desta seqüência, diversos outros haplótipos (de ocorrência restrita) podem ter se derivado através de mutações pontuais. Nenhuma diferenciação genética significante foi observada entre as regiões Sul e Sudeste.
\end{abstract}

Palavras-chave: Lontra longicaudis, DNA mitocondrial, região controladora, diversidade genética.

\section{Introduction}

Accurate estimates of genetic diversity and its patterns of geographic structuring are extremely important for the ultimate adequacy and success of conservation efforts. However, due to the elusive behavior of most carnivore species, this kind of information is often very difficult to obtain, as is the case of Lontra longicaudis (Mamalia, Carnivora, Mustelidae). This medium-sized, semi-aquatic carnivore, is widely distributed in the Neotropical region, and currently faces threats such as habitat destruction and pollution in several parts of its distribution (Chehébar, 1990). Information on the genetic diversity of this species, and its connection with ecological data, are required steps towards the effective conservation and management of this organism. 
The mitochondrial DNA (mtDNA) control region has been extensively used in conservation studies of many species of vertebrates (Eizirik et al., 1998; Möller et al., 2001; Montoya-Burgos, 2003; Cantanhede et al., 2005; Márquez et al., 2006; Barnett et al., 2006; Tchaicka et al., 2007). Due to the high polymorphism on its 5' end in vertebrates (Avise, 1994; Taberlet, 1996), this segment has been widely used in populational studies of mustelids such as Gulo gulo (Wilson et al., 2000; Chappell et al., 2004), Mustela putorius (Davison et al., 2000), Martes foina (Davison et al., 2001), Enhydra lutris (Larson et al., 2002), and Lutra lutra (Mucci et al., 1999; Cassens et al., 2000; Pérez-Haro et al., 2005).

Although the Neotropical otter is one of the least known otter species, several ecological studies focusing on L. longicaudis have been conducted in different localities in Brazil (Pardini, 1999; Colares and Waldemarin, 2000; Quadros and Monteiro-Filho, 2001). In contrast, no study has been published so far addressing the genetic variability of this species. For this reason, in this paper we aim to describe and analyze the diversity of the 5 ' portion of the mtDNA control region in this species, based on samples collected in Southern and Southeastern Brazil.

\section{Material and Methods}

Tissue (footpad, muscle and kidney) and blood samples were obtained from 20 individuals of L. longicaudis from several localities in the South and Southeast regions of Brazil. The former includes the states of Rio Grande do Sul, Santa Catarina, and Paraná; the latter includes samples from the states of São Paulo, Rio de Janeiro, and Minas Gerais. In addition, four fecal samples were obtained by collaborators working in the field or with captive individuals (Table 1). Both tissue and scat samples were preserved

Table 1. Samples of Lontra longicaudis and Pteronura brasiliensis used in this study.

\begin{tabular}{|c|c|c|c|c|}
\hline Sample ID & Material & Geographic Origin $^{a}$ & $\begin{array}{c}\text { Geographic } \\
\text { region }\end{array}$ & Source Institution / Contact \\
\hline bLlo01 & muscle & RS & Southern & G. Bencke and JR. Marinho \\
\hline bLlo03 & muscle & RS & Southern & Carnívoros do RS Project \\
\hline bLlo04 & footpad & $\mathrm{RS}$ & Southern & Carnívoros do RS Project \\
\hline bLlo05 & muscle & Gravataí, RS & Southern & GL.Gonçalves \\
\hline bLlo06 & muscle & $\mathrm{RS}$ & Southern & PH. Ott \\
\hline bLlo07 & muscle & Curumim, RS & Southern & P. Colombo \\
\hline bLlo12 & muscle & Dois Irmãos, RS & Southern & $\begin{array}{l}\text { Prefeitura de Dois Irmãos / } \\
\text { I. Fick }\end{array}$ \\
\hline bLlo26 & faeces & Eldorado do Sul, RS & Southern & $\begin{array}{l}\text { Sapucaia do Sul Zoo / } \\
\text { R. von Hohendorff }\end{array}$ \\
\hline bLlo37 & faeces & Nova Santa Rita, RS & Southern & Canoas Minizoo / M. Martins \\
\hline bLlo42 & muscle & Capela de Santana, RS & Southern & Canoas Minizoo / M. Martins \\
\hline bLlo58 & muscle & Osório, RS & Southern & $\begin{array}{l}\text { P. Colombo, C. Zank and L. } \\
\text { Volkmer }\end{array}$ \\
\hline bLlo02 & muscle & $\mathrm{SC}$ & Southern & Sapucaia do Sul Zoo \\
\hline bLlo34 & muscle & Blumenau, SC & Southern & FURB / S. Althoff \\
\hline bLlo29 & blood & Foz do Iguaçu, PR & Southern & São Paulo Zoo / K. Kassaro \\
\hline bLlo38 & muscle & P. N. de Ilha Grande, PR & Southern & L. Kroposki \\
\hline bLlo57 & blood & Paranapanema River, PR & Southeastern & L. Koproski \\
\hline bLlo10 & kidney & Mogi-Mirim, SP & Southeastern & CENAP/IBAMA \\
\hline bLlo36 & faeces & Sumaré, SP & Southeastern & Campinas Zoo / E. Ferraz \\
\hline bLlo39 & muscle & Ribeirão Preto, SP & Southeastern & $\begin{array}{l}\text { Ribeirão Preto Zoo / M. dos } \\
\text { Santos }\end{array}$ \\
\hline bLlo51 & faeces & P.E. da Ilha do Cardoso, SP & Southeastern & E. Nakano \\
\hline bLlo14 & muscle & Angra dos Reis, RJ & Southeastern & HF. Waldemarin \\
\hline bLlo15 & muscle & Guaratiba, RJ & Southeastern & HF. Waldemarin \\
\hline bLlo16 & muscle & Barra, RJ & Southeastern & HF. Waldemarin \\
\hline bLlo30 & blood & Belo Horizonte, MG & Southeastern & São Paulo Zoo / K. Kassaro \\
\hline bPbr01 & muscle & Negro River, Pantanal, MS & Center-West & HF. Waldemarin \\
\hline bPbr02 & muscle & Negro River, Pantanal, MS & Center-West & HF. Waldemarin \\
\hline
\end{tabular}

aRS: Rio Grande do Sul State; SC: Santa Catarina State; PR: Paraná State; SP: São Paulo State; RJ: Rio de Janeiro State; MG: Minas Gerais State; MS: Mato Grosso do Sul State. bLlo: Lontra longicaudis; bPbr: Pteronura brasiliensis 
in ethanol $96 \%$ and blood samples were preserved in a salt saturated solution (100mM Tris, 100mM EDTA, $2 \%$ SDS). All samples were stored at $-20{ }^{\circ} \mathrm{C}$ prior to DNA extraction. Total DNA was extracted from tissue and blood samples following a standard phenol-chloroform protocol (Sambrook et al., 1989). DNA from scats was recovered using the QIAamp DNA Stool Mini Kit (Qiagen). The scat DNA extractions were carried out in a separate room to avoid contamination with other DNA sources.

The 5' portion of the mtDNA control region (CR), containing the first hypervariable segment, was amplified by Polymerase Chain Reaction (PCR) using the primer pair MTLPRO2 and CCR-DR1 (Tchaicka et al., 2007). Since the DNA present in scat samples is often degraded and at low concentrations, the sequencing of long fragments from this type of material can be difficult. To address this issue, we developed internal primers for the otter CR, dividing it into three shorter fragments of approximately 250 base pairs (bp) each. We did this by initially sequencing multiple $L$. longicaudis individuals for the complete CR segment, along with two samples of the distantly related giant otter (Pteronura brasiliensis Gmelin, 1788), to identify internal segments for primer design that will likely be conserved across the subfamily Lutrinae. The resulting primers are: LonCR-R1 (reverse to MTLPRO2) (5'-ATGGTTTCTCGAGGCATGGT-3'), LonCR-F2 (forward to CCR-DR1) (5'-AACTATACCTGGCATCTGGTTCTT-3'), and the internal pair LonCRF1 (5' - GGTTTGCCCCATGCATATAA-3') + LonCRR2 (5'-TGTGTGATCATGGGCTGATT-3').

Each $20 \mu \mathrm{L}$ PCR reaction contained $1-2 \mu \mathrm{L}$ of empirically diluted DNA, 1x PCR Buffer (Invitrogen), 1.5-2.0 $\mathrm{mM} \mathrm{MgCl}_{2}, 200 \mu \mathrm{M}$ dNTPs, $0.2 \mu \mathrm{M}$ of each primer, and 0.5 unit of Taq DNA Polymerase (Invitrogen). The PCR conditions were the following: 10 cycles (Touchdown) of $94{ }^{\circ} \mathrm{C}$ for 45 seconds, 60-51 ${ }^{\circ} \mathrm{C}$ for 45 seconds, and $72{ }^{\circ} \mathrm{C}$ for 1.5 minute; fol- lowed by 30 cycles of $94{ }^{\circ} \mathrm{C}$ for 45 seconds, $50{ }^{\circ} \mathrm{C}$ for 45 seconds, and $72{ }^{\circ} \mathrm{C}$ for 1.5 minute, and final extension of $72{ }^{\circ} \mathrm{C}$ for 3 minutes. Products were checked on a $1 \%$ agarose gel stained with ethidium bromide, purified with PEG8000, sequenced using the DYEnamic ET Dye Terminator Sequencing Kit (GE Healthcare), and analyzed in a MegaBACE 1000 automated sequencer (GE Healthcare). Sequences were deposited in GenBank under accession numbers EU251949-EU251960.

Sequences were visually checked and manually corrected using CHROMAS 2.0 (http://www.technelysium. com.au/chromas.html), and subsequently aligned with the CLUSTALW algorithm implemented in MEGA 3.1 (Kumar et al., 2004). MEGA was also used to perform sequence comparisons and computations of variability. The program Network 4.1.1.2 (www.fluxus-engineering.com) was used to construct a haplotype network depicting the evolutionary relationships among the sequences. To test whether there is genetic differentiation between the Southern and Southeastern Brazilian regions, we employed an Analysis of Molecular Variance (AMOVA) approach (Excoffier et al., 1992) implemented in ARLEQUIN 2.0 (Schneider et al., 2000). Additional population genetic analyses were performed with DnaSP (Rozas et al., 2003).

\section{Results}

A fragment of 516 bp was obtained from the 5' end of the mtDNA control region of 24 Neotropical otters. Removal of a 25 bp portion whose alignment was ambiguous resulted in a final data set of $491 \mathrm{bp}$, which was used in all subsequent analyses. Timines and adenines were quite prevalent in the otter CR (T: 30.12\%; A: 26.50\%; C: $24.44 \%$; G: $18.94 \%$ ). Fifteen polymorphic positions were identified (seven of which were parsimony-informative), allowing the detection of 12 different mitochondrial haplotypes (Table 2). The overall observed

Table 2. List of individuals that bear each mtDNA control region haplotype. The localities of occurrence of each haplotype are also indicated.

\begin{tabular}{lll}
\hline Haplotype $^{\mathrm{a}}$ & \multicolumn{1}{c}{ Individuals } & \multicolumn{1}{c}{ Haplotype occurrence } \\
\hline L-1 & bLlo01, bLlo03,bLlo24 & Rio Grande do Sul \\
L-2A & bLlo02, bLlo06, bLlo12, bLlo14, & Rio Grande do Sul, Santa Catarina, Paraná \\
& bLlo15, bLlo26, bLlo34, bLlo38, bLlo58 & and Rio de Janeiro \\
bLlo30 & Minas Gerais \\
L-2B & bLlo05, bLlo39 & Rio Grande do Sul and São Paulo \\
L-3 & bLlo07 & Rio Grande do Sul \\
L-4 & bLlo10 & Sao Paulo \\
L-5 & bLlo16 & Rio de Janeiro \\
L-6 & bLlo29, bLlo37 & Paraná and Rio Grande do Sul \\
L-7 & bLlo36 & São Paulo \\
L-8 & bLlo42 & Rio Grande do Sul \\
L-9 & bLlo51 & São Paulo \\
L-10 & bLlo57 & Paraná \\
L-11 & Sand & \\
\hline
\end{tabular}

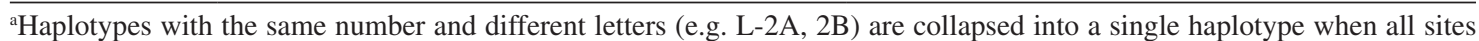
with missing information or indels are excluded (e.g. Figure 1). bLlo: Lontra longicaudis; bPbr: Pteronura brasiliensis 
haplotype diversity was high (0.8188), but the nucleotide diversity was low, even considering both sampled regions (0.0049; SE: 0.0015) and within each geographic region (Table 3). Haplotype L-2A was clearly the most common and, along with haplotype L-3, it was found in both analyzed regions (see Tables 1 and 2), while the other 10 haplotypes were restricted to either the South or the Southeast. The haplotype network (Figure 1) shows some reticulation, indicating the occurrence of homoplasy likely due to saturation at variable sites. The haplotypes were divergent mostly by a single difference, indicating a recent origin and no major divergence among these sequences. The analysis of genetic differentiation based on the AMOVA approach showed no evidence for significant divergence between the Southern and Southeastern populations $\left(\mathrm{F}_{\mathrm{ST}}=0.0511 ; \mathrm{p}=0.1113\right)$. To assess whether alternative subdivision scenarios could indicate any genetic partitioning, we also tested two other structuring schemes allowed by our sampling: (i) placing the haplotypes sampled in Paraná State (the Northernmost of the Southern States) into the Southeastern population; and (ii) considering Rio Grande do Sul State (the Southernmost of all sampled states) as a separate population from the other areas. Both scenarios yielded non-significant $\mathrm{F}_{\mathrm{ST}}$ values (scheme (i): $\mathrm{F}_{\mathrm{ST}}=0.0048 ; \mathrm{p}=0.3467$; scheme (ii): $\mathrm{F}_{\mathrm{ST}}=-0.0097 ; \mathrm{p}=0.5009$ ), supporting the inference of no genetic subdivision between these areas.

\section{Discussion}

The Neotropical otter populations analyzed here exhibit low levels of nucleotide variation on the 5' end of the mitochondrial DNA control region, which is known to be a highly polymorphic marker in other vertebrates (Avise, 1994). However, they present high haplotype diversity, indicating that they are not genetically depauperate, but rather may result from a recent process of population diversification in this region.

Observed levels of genetic variability in Neotropical otters were similar or lower $(\pi=0.0049 \pm 0.0015$; $\mathrm{h}=0.8188 \pm 0.0052)$ than values observed for other vertebrates. For example, Eizirik et al. (2001) found that the nucleotide diversity of jaguars (Panthera onca Linnaeus, 1758) throughout their range is 0.00771 (SE: 0.00010); Cantanhede et al. (2005) obtained nucleotide and haplotype diversity values for the Amazonian mana- tee (Trichechus inunguis Natterer, 1883) of 0.624 (SE: 0.384 ) and 0.887 (SE: 0.026), respectively. Moreover, the same control region segment was used by Tchaicka et al. (2007) in phylogeographic analyses of the crabeating fox (Cerdocyon thous Linnaeus, 1766), a genetically diverse Neotropical canid. Indeed, the comparison between $L$. longicaudis and $C$. thous indicates that the nucleotide diversity is substantially higher in the latter ( $\pi=0.019 \pm 0.002$ ), while the haplotype diversity is similar in both species ( $\mathrm{h}=0.83 \pm 0.032$ in $C$. thous).

Comparing the results obtained in this study with analyses performed with other mustelids, we observed that the levels of nucleotide variability estimated for the sampled L. longicaudis populations are among the lowest recorded so far in this carnivore family (e.g. Mustela lutreola $(\pi=0.0012 \pm 0.0003$ in Southeastern Europe; and $0.012 \pm 0.0014$ in Northeastern Europe populations; Michaux et al., 2005), Gulo gulo $(\pi=0.0055 \pm 0.0040$ and $0.0153 \pm 0.0091$ in North and Prairie Canadian populations, respectively; Chappell et al., 2004), Enhydra lutris $(\pi=0.098 \pm 0.029$; Larson et al., 2002). Nevertheless, the nucleotide diversity of $L$. longicaudis is still much

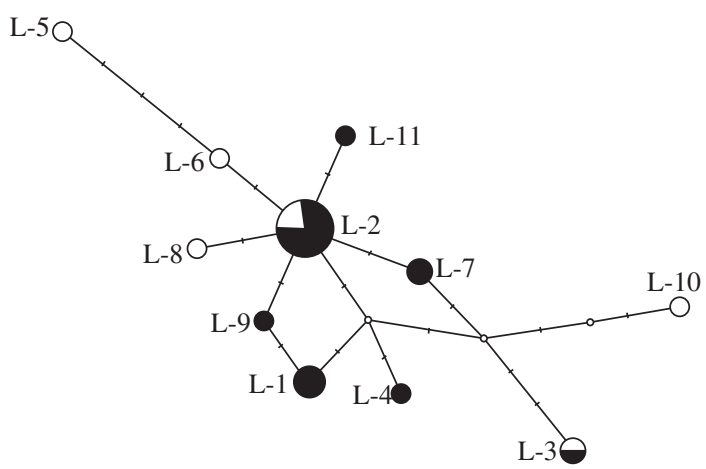

Figure 1. Median-joining network of L. longicaudis mtDNA control region haplotypes (using 491 bp; all sites containing indels or missing information were excluded). Each haplotype is represented by a circle, whose area is proportional to its population frequency. White circles (or areas within circles) represent samples from Southeastern Brazil, whereas black coloration indicates samples from Southern Brazil. Bars on branches indicate nucleotide substitutions inferred to have occurred in each lineage.

Table 3. mtDNA control region diversity estimates for the Neotropical otter.

\begin{tabular}{lrcrccc}
\hline $\begin{array}{c}\text { Geographic } \\
\text { Region }\end{array}$ & $\mathbf{N}$ & $\begin{array}{c}\text { N. of } \\
\text { haplotypes }\end{array}$ & $\mathbf{S}^{\mathbf{a}}$ & $\mathbf{P I}^{\mathbf{b}}$ & $\pi^{\mathbf{c}}$ & $\mathbf{h}^{\mathbf{d}}$ \\
\hline Southern & 16 & 7 & 9 & 3 & $0.0039 \pm 0.0014$ & $0.7917 \pm 0.0078$ \\
Southeastern & 8 & 7 & 10 & 4 & $0.0067 \pm 0.0021$ & $0.9167 \pm 0.0085$ \\
Total & 24 & 12 & 15 & 7 & $0.0049 \pm 0.0015$ & $0.8188 \pm 0.0052$ \\
\hline
\end{tabular}

${ }^{\mathrm{a}} \mathrm{S}=$ Polymorphic sites.

${ }^{\mathrm{b}} \mathrm{PI}=$ Parsimony-informative sites.

${ }^{\mathrm{c}}$ Nucleotide diversity per site.

${ }^{\mathrm{d}}$ Haplotype diversity. 
higher than the levels observed so far for Lutra lutra in Europe ( $\pi=0.0006$; Ferrando et al., 2004).

In contrast to the low nucleotide diversity, the haplotype diversity found in the Neotropical otter is much higher than levels observed for other otter species, such as Enhydra lutris ( $\mathrm{h}=0.412$; Larson et al., 2002) and Lutra lutra ( $\mathrm{h}=0.16 \pm 0.06$; Ferrando et al., 2004). In contrast to L. longicaudis, large-scale studies on European populations of Lutra lutra based on $300 \mathrm{bp}$ of the 5' end mtDNA control region have so far described only six haplotypes, all of which differing from each other by a single nucleotide, demonstrating very low levels of genetic variability for that species (Effenberger and Suchentrunk, 1999; Mucci et al., 1999; Cassens et al., 2000; Pérez-Haro et al., 2005). Future assessments using standardized DNA segments and analytical methods should allow more detailed comparisons of the genetic diversity and underline the demographic history of the world's otter species.

This study provides a first description of the genetic variability of the Neotropical otter, based on the analysis of some populations originated from only a small part of the species' geographic distribution. The observed patterns suggest a recent origin and possibly a high demographic connectivity between the sampled areas, with no major genetic structuring. However, the samples outside Rio Grande do Sul State were very reduced $(\mathrm{N}=9$ over $3,000 \mathrm{~km}$ ), which could also be responsible for the lack of significance in the $\mathrm{F}_{\mathrm{ST}}$ comparisons. Further studies must be conducted to provide a broader perspective on the genetic diversity of this species in its entire geographic range. The expansion of these genetic analyses, both in terms of geographic coverage and use of multiple marker systems, should contribute to increase the current knowledge on the history and population biology of the Neotropical otter, aiding in the development and implementation of conservation strategies targeting this species and its habitats.

Acknowledgments - We would like to thank the people and institutions that helped us to collect the samples used in this study, and to an anonymous reviewer who provided useful comments on a previous version of this paper. The authors are also grateful to Centro Nacional de Pesquisas para a Conservação de Predadores Naturais - CENAP/IBAMA, Instituto Pró-Carnívoros, and CNPq for the financial support of this project.

\section{References}

AVISE, JC., 1994. Molecular markers, natural history $e$ evolution. New York, Chapman \& Hall, 511p.

BARNETT, R., YAMAGUCHI, N., BARNES, I. and COOPER, A., 2006. Lost populations and preserving genetic diversity in the lion Panthera leo: implications for its ex situ conservation. Conserv. Genet., vol. 7, no. 4, p. 507-514.

CANTANHEDE, AM., DA SILVA, VMF., FARIAS, IP., HRBEK, T., LAZZARINI, SM. and ALVES-GOMES, J., 2005. Phylogeography and population genetics of the endangered
Amazonian manatee, Trichechus inunguis Natterer, 1883 (Mammalia, Sirenia). Mol. Ecol., vol. 14, no. 2, p. 401-413.

CASSENS, I., TIEDEMANN, R., SUCHENTRUNK, F. and HARTL, GB., 2000. Mitochondrial DNA variation in the European otter (Lutra lutra) and the use of spatial autocorrelation analysis in conservation. J. Hered., vol. 91, no. 1, p. 31-41.

CHAPPELL, DE., VAN DEN BUSSCHE, RA., KRIZAN, J. and PATTERSON, B., 2004. Contrasting levels of genetic differentiation among populations of wolverines (Gulo gulo) from northern Canada revealed by nuclear and mitochondrial loci. Conserv. Genet., vol. 5, no. 6, p. 759-767.

CHEHÉBAR, CE., 1990. Action Plan from Latin American Otters. In FOSTER-TURLEY, P., MACDONALD, S. and MASON, C. (eds.). Otters: An Action Plan for their Conservation. IUCN Otter Specialist Group, p. 64-73.

COLARES, EP. and WALDEMARIN, HF., 2000. Feeding of the neotropical river otter (Lontra longicaudis) in the coastal region of the Rio Grande do Sul State, Southern Brazil. IUCN Otter Specialist Group Bulletin, vol.17, no. 1, p. 6-13.

DAVISON, A., GRIFFITHS, HI., BROOKES, RC., MORAN, T., MACDONALD, D., SIDOROVICH, V., KITCHENER, AC., IRIZIAR, I., VILLATE, I., GONZÁLES-ESTEBAN, J., CEÑA, A., MOYA, I. and PALAZÓN, S., 2000. Mitochondrial DNA and paleontological evidence for the origins of endangered European mink, Mustela lutreola. Anim. Conserv., vol. 3, no. 4, p. 345-355.

DAVISON, A., BIRKS, JDS., BROOKES, RC., MESSENGER, JE. and GRIFFITHS, HI., 2001. Mitochondrial phylogeography and population history of pine martens Martes martes compared with polecats Mustela putorius. Mol. Ecol., vol. 10, no. 10, p. $2479-2488$.

EFFENBERGER, S. and SUCHENTRUNK, F., 1999. RFLP analyses of the mitochondrial DNA of otters (Lutra lutra) from Europe - implications for conservation of a flagship species. Biol. Conserv., vol. 90, no. 3, p. 229-234.

EIZIRIK, E., BONATTO, SL., JOHNSON, WE., CRAWSHAW, Jr. PG., VIÉ, JC., BROUSSET, DM., O'BRIEN, SJ. and SALZANO, FM., 1998. Phylogeographic patterns and mitochondrial DNA control region evolution in two Neotropical cats (Mammalia, Felidae). J. Mol. Evol., vol. 47, no. 5, p. 613-624.

EIZIRIK, E., KIM, J., MENOTTI-RAYMOND, M., CRAWSHAW, Jr. PG., O'BRIEN, SJ. and JOHNSON, WE., 2001. Phylogeography, population history e conservation of jaguars (Panthera onca, Mammalia, Felidae). Mol. Ecol., vol. 10 , no. 1 , p. $65-79$.

EXCOFFIER, L., SMOUSE, P. and QUATTRO, J., 1992. Analysis of Molecular Variance inferred from metric distances among DNA haplotypes: application to human mitochondrial DNA restriction data. Genetics, vol. 131, no. 2, p. 479-491.

FERRANDO, A., PONSÀ, M., MARMI, J. and DOMINGOROURA, X., 2004. Eurasian otters, Lutra lutra, have a dominant mtDNA haplotype from the Iberian Peninsula to Scandinavia. $J$. Hered., vol. 95, no. 5, p. 430-435.

KUMAR, S., TAMURA, K. and NEI, M., 2004. MEGA3: Integrated software for molecular evolutionary genetics analysis and sequence alignment. Brief Bioinf., vol. 5, no. 2, p. $150-163$. 
LARSON, SE., JAMESON, RJ., BODKIN, JL., STAEDLER, M. and BENTZEN, P., 2002. Microsatellite DNA and mtDNA variation within and among remnant and translocated sea otter, Enhydra lutris, populations. J. Mamm., vol. 83, no. 3, p. 893-906.

MÁRQUEZ, A., MALDONADO, JE., GONZÁLEZ, S., BECCACECI, MD., GARCIA, JE. and DUARTE, JMB., 2006. Phylogeography and Pleistocene demographic history of the endangered marsh deer (Blastocerus dichotomus) from the Río de La Plata Basin. Conserv. Genet., vol. 7, no. 4, p. 563-575.

MICHAUX, JR., HARDY, OJ., JUSTY, F., FOURNIER, P., KRANZ, A., CABRIA, M., DAVISON, A., ROSOUX, R. and LIBOIS, R., 2005. Conservation genetics and population history of the threatened European mink Mustela lutreola, with an emphasis on the West European populations. Mol. Ecol., vol. 14, no. 8, p. 2373-2388.

MÖLLER, LM., BEHEREGARAY, LB., HARCOURT, RG. and KRÜTZEN, M., 2001. Alliance membership and kinship in wild male bottlenose dolphins (Tursiops aduncus) of southeastern Australia. Proc. R. Soc. Lon., B, vol. 268, no. 1479, p. 1941-1947.

MONTOYA-BURGOS, JI., 2003. Historical biogeography of the catfish genus Hypostomus (Siluriformes: Loricariidae), with implications on the diversification of Neotropical ichthyofauna. Mol. Ecol., vol. 12, no. 7, p. 1855-1867.

MUCCI, N., PERTOLDI, C., MADSEN, AB., LOESCHCKE, V. and RANDI, E., 1999. Extremely low mitochondrial DNA control-region sequence variation in the otter Lutra lutra population of Denmark. Hereditas, vol. 130, no. 3, p. 331-336.

PARDINI, R., 1999. Use of shelters by the neotropical river otter (Lontra longicaudis) in an Atlantic Forest stream, southeastern Brazil. J. Mamm., vol. 80, no. 2, p. 600-610.

PÉREZ-HARO, M., VIÑAS, J., MAÑAS, F., BATET, A., RUIZ-OLMO, J. and PLA, C., 2005. Genetic variability in the complete mitochondrial control region of the Eurasian Otter (Lutra lutra) in the Iberian Peninsula. Biol. J. Linn. Soc., vol. 86, no. 4, p. 397-403.

QUADROS, J. and MONTEIRO-FILHO, ELA., 2001. Diet of the Neotropical otter, Lontra longicaudis, in Atlantic Forest area, Santa Catarina State, southern Brazil. Stud. Neotrop. Fauna Environ., vol. 36, no. 1, p. 15-21.

ROZAS, J., SÁNCHEZ-DEL BARRIO, JC., MESSEGUER, X. and ROZAS, R., 2003. DNASP, DNA polymorphism analyses by the coalescent and others methods. Bioinformatics, vol. 19, no. 18 , p. $2496-2497$.

SAMBROOK, J., FRITSCH, EF. and MANIATIS, T., 1989. Molecular Cloning. $2^{\text {nd }}$. edition. New York, Cold Spring Harbor Laboratory Press.

SCHNEIDER, S., ROESSLI, D. and EXCOFFIER, L., 2000. ARLEQUIN: A Software for Population Genetic Data Analysis, Version 2.0. Geneva, Switzerland, Genetics and Biometry Laboratory, Department of Anthorpology, University of Geneva. 140p.

TABERLET, P., 1996. The use of mitochondrial DNA control region sequencing in conservation genetics. In SMITH, TB. and WAYNE, RK. (eds.). Molecular approaches in conservation. New York, Oxford University Press, p. 125-142.

TCHAICKA, L., EIZIRIK, E., OLIVEIRA, TG., CÂNDIDO, Jr JF., FREITAS, TRO., 2007. Phylogeography and population history of the crab-eating fox (Cerdocyon thous). Mol. Ecol., vol. 16 , no. 4 , p. 819-838.

WILSON, GM., VAN DEN BUSSCHE, RA., KENEDY, PK., GUNN, A. and POOLE, K., 2000. Genetic variability of wolverines (Gulo gulo) from the Northwest territories, Canada: conservation implications. J. Mamm., vol. 81, no. 1, p. 186-196. 